\title{
Solidarity Actions Based on Religious Plurality
}

\author{
Lena de Botton ${ }^{1} \mathbb{1}$, Emilia Aiello ${ }^{2,3}$, Maria Padrós ${ }^{4, *}$ and Patricia Melgar 5 \\ 1 Department of Sociology, University of Barcelona, 08034 Barcelona, Spain; lenadebotton@ub.edu \\ 2 Kennedy School of Government, Harvard University, Cambridge, MA 02138, USA; \\ aielloemilia_aiello@hks.harvard.edu \\ 3 Department of Sociology, Autonomous University of Barcelona, 08193 Cerdanyola del Vallès, Spain \\ 4 Department of Didactics and Educational Organization, University of Barcelona, 08035 Barcelona, Spain \\ 5 Department of Pedagogy, University of Girona, 17004 Girona, Spain; patricia.melgar@udg.edu \\ * Correspondence: mariapadros@ub.edu
}

Citation: de Botton, Lena, Emilia Aiello, Maria Padrós, and Patricia Melgar. 2021. Solidarity Actions Based on Religious Plurality. Religions 12: 564. https://doi.org/10.3390/ rel12080564

Academic Editors: Antony

W. Alumkal, Svetlana Sharonova and Marta Soler

Received: 15 May 2021

Accepted: 15 July 2021

Published: 22 July 2021

Publisher's Note: MDPI stays neutral with regard to jurisdictional claims in published maps and institutional affiliations.

Copyright: (c) 2021 by the authors. Licensee MDPI, Basel, Switzerland. This article is an open access article distributed under the terms and conditions of the Creative Commons Attribution (CC BY) license (https:/ / creativecommons.org/licenses/by/ $4.0 /)$.

\begin{abstract}
The successive crises experienced recently (financial crisis in 2008, refugees in 2015 and the current crisis resulting from COVID) have led to surges in discrimination, racism and lack of solidarity between groups. However, these same crises have inspired important manifestations of solidarity with a significant social impact (improving people's lives) for many groups and in very different areas. This article focuses on two solidarity initiatives (interreligious language pairs and a cooperative) that contribute to overcoming inequalities and the social exclusion of the most vulnerable groups, to explore whether religious plurality and the interreligious dialogue present in these initiatives are a favourable element for solidarity.
\end{abstract}

Keywords: solidarity; religious plurality; social impact

\section{Introduction}

An increase in lack of solidarity, hate speech discourse and discrimination against certain groups (Habermas 1999) often occurs after a crisis (for instance, the financial crisis of 2008, the humanitarian crisis of refugees that began in 2015 or the current consequences of the COVID-19 pandemic). In this study we have considered the variable of religion, because the data for Europe indicate the persistence of discriminatory attitudes especially towards specific groups such as Jews, Muslims and Roma, or in general anti-immigration terms (Ekman 2019). Indeed, one of the main sources of discrimination stems from religious motivations. Muslim and Jewish communities are the second and third most socially rejected communities according to several surveys such as the World Values Survey (Haerpfer et al. 2020). According to the Pew Research Center survey for Western Europe, for example, only $57 \%$ of respondents in Italy would accept a Jewish family member and 43\% would accept a Muslim member (Pew Research Center 2018).

This negative attitude increases when the ideology of the respondent approaches the right or the extreme right. In recent years we have witnessed support for populist or extreme right-wing parties that maintain a robust anti-immigration discourse in Europe, with enormous social, economic and political consequences (European Commission 2019). For example, since 2010 the majority political force in Hungary has been the far-right Fidesz party. In a country where there is practically no immigrants, the Fidesz party has been promoting intense anti-immigration propaganda (Than and Szakacs 2018), referencing a "Muslim invasion" and defending the need to create lists of Jews and Roma to guarantee the country's security. In Sweden, the SD-Democrats of Sweden-party became the third force in the parliament with anti-migration and especially anti-Muslim proclamations, considering these groups a risk for social decomposition. The far-right party Alternative für Deutschland (AfD) became the third force in the German federal parliament in 2017. Among many other examples, the National Front in France (with a quarter of the population's support) points unambiguously to immigration as responsible for crime and 
unemployment rates (Perrineau 2014). In Spain, the appearance of the extreme-right party VOX, which entered in the Spanish parliament in 2019, officially requested removing from the Penal Code the mention of "racist and anti-Semitic motives" in the definition of hate crimes.

The prejudices that have manifested and become visible in the successive crises are not new. As many authors have stated (Balboa and Herzog 2016; Perednik 2018; Wieviorka 1992), prejudice has never disappeared throughout history and spreads without inhibition in times of crisis. Prejudice does not require contact with the groups discriminated against in order for prejudiced individuals to speak out (Torrens 2006); prejudice has a great capacity to adapt to different historical moments and to different political systems and ideologies. The only thing that changes is its public expression over time or according to society, always appealing to people's fears (Flecha 1999). Consequently, introducing the emotional dimension through interreligious interactions increases the possibility of overcoming prejudice (Nussbaum 2001).

Despite this context, it is essential to point out that actions of solidarity also appear. This solidarity is fundamental to understanding the social cohesion of our societies. In addition to reflecting the existing racism, the survey conducted by the Pew Research Center also draws attention to the fact that the interaction with religious minorities, such as Islam for example, reduces individual negative attitudes towards these groups (Pew Research Center 2018). This is precisely what interreligious dialogue movements, or organisations based on the principle of egalitarian dialogue, do to manage internal plurality (Campdepadrós-Cullell et al. 2021). Therefore, this paper further investigates the association between engaging in actions of solidarity and religious plurality.

\section{State of the Art}

The concept of solidarity is complex. According to Rorty (1989), the traditional explanation of "solidarity" "is to say that there is something within each of us-our humanitywhich is something present in other human beings" (p. 189). Throughout the literature on solidarity, Habermas explains that solidarity is about "the welfare of consociates who are intimately linked in an intersubjectively shared form of life-and thus also the maintenance of this form of life itself" (Habermas 1990, p. 244). Solidarity "involves active support for others, not just passive empathy" (Baker et al. 2009, p. 37). We focus on this idea because it is a powerful concept that motivates action. The force contained in solidarity is an important starting point for the present analysis. Halldenius says that solidarity is a "benevolent motivation towards certain others" (1998, p. 335), and "to feel solidarity is to be morally motivated" (p. 346). From a political perspective, placing solidarity within a governmental framework increases the level of commitment towards it as a society and among its members. Inclusion and "the right to have rights" (Oman 2010) are relevant ideas related to solidarity and political theories.

Religions are intrinsically related to solidarity and helping others. Durkheim (1912) already emphasized the role that religious membership could play in social cohesion by creating a sense of community belonging and avoiding the risk of loss of meaning. Several authors addressing the current challenge of European integration have developed an entire series of arguments concerning solidarity where religious belief and practice, the authors argue, makes it more prone to redistribution and acceptance (Bauhr and Charron 2020). Indeed, values of social justice, hospitality and solidarity are guiding principles of different religious traditions (Miles-Tribble 2020), including tolerance and solidarity with members of other religious traditions (Fadel 2020).

The argument of religion as a source of solidarity is well documented in studies that analyse expressions of solidarity in current situations. Hein and Niazi (2016) argue that the narratives of different religious traditions contribute to positive socialization and towards hospitality with those who have to flee and seek refuge. Addressing the situation on the North American border, Ahn (2019) calls on members of the Christian and Buddhist communities in the United States to adopt values from their religious traditions 
to face the migration crisis. In the same vein, Kyriakidou (2021) confronts the European humanitarian crisis concerning refuges in Greece, and stresses the value of hospitality that different religious traditions share, as a driver for increasing the acceptance of receiving refugees and migrants. Mim (2020) examines the impacts of religious practices on protecting the socioeconomic and cultural rights of Rohingya refugees in Bangladesh through an empirical study carried out in eight different camps. She documents how refugees, through different religious activities and practices, in this case Islamic, protect their cultural identities, negotiate with local government agents and maintain solidarity with the host communities in their camp. Religion provides them with a source of identity and becomes an engine of action towards the community. Indeed, Mim (2020) describes how many secular humanitarian projects are often challenged, resisted or even rejected by the refugees in these refugee camps. Moreover, projects developed by religious entities gain a higher degree of trust, despite not being of Islamic tradition as most of the refugees in the camps are. Mim states that secular projects do not manage to address their network relationships and the community identification offered by religious traditions (Mim 2020), and concludes that religious entities are more effective in preventing and reducing exclusion than secular development agencies. Even in today's secular societies, the principle of hospitality has a close connection with and origin in religious traditions. Currently, welfare states mirror this principle to manage cultural and ethnic diversity (George 2020). The relationship between religion and solidarity is also pointed out by Steinbach and Silverstein (2020) with regard to intergenerational solidarity. Analysing Germany's religious climate, Steinbach and Silverstein point out that affiliation with a religion is associated with higher intergenerational relationship strength, while this association is strongest in the western part of Germany due to its more robust religious tradition (Steinbach and Silverstein 2020).

Beyond the impact of religion on solidarity towards others regardless of their own religious denomination, scientific literature also acknowledges the positive impacts of interreligious dialogue (Gustafson 2020). Scholar Amartya Sen (2019) points out the spaces of solidarity that are created between women of different religious traditions. He takes the case of women working in domestic service in India. Sharing different forms of inequalitybecause they are women and because they are from a disadvantaged social class-enables dialogues and complicities in moments of rest (Sen 2019). Despite their religious differences, the author states that they create bonds of solidarity and mutual aid through dialogue and respect. Consequently, these women acquire an interreligious perspective when they discuss fundamental aspects of their existence, such as gender or social class.

Miles-Tribble (2020) reflects on the strength of interreligious discourse in social transformation, thanks to the values of justice and shared ethical actions to reduce existing social inequalities. In this sense, the author makes a critical reflection and offers a set of criteria to favour collaborative change agents that impact social policies. Miles-Tribble also presents the Black Lives Matter movement as one of many solidarity actions that become agents of change, taking as their guiding principle the values of social justice of different religious traditions (Miles-Tribble 2020).

In line with Sen (2019) and Miles-Tribble (2020), there are many other examples that show that egalitarian dialogue between religious traditions have a positive impact in reducing social inequalities through collective action (Edwards 2018; Ferraro 2018; Hein and Niazi 2016; Robra 2000; Sen 2019). Indeed, there is a growing interest in interreligious dialogue as an essential mechanism for the effective management of diversity. In her analysis of the interfaith movement in US higher education, Edwards (2018) points out that this mobilisation is inspired mainly by current global events aimed at promoting tolerance concerning the plurality of religious traditions. This movement recognises the religious fact not so much from its transcendental or spiritual aspect but as a social fact.

Interreligious dialogue provides answers to the difficulties posed by a narrow concept of the neutrality of public space as homogenisation or assimilation (Berger 2014). In fact, Astor et al. (2019) focus on the debate on the mutual accommodation of religious diversity and the recognition of religious fact as a social phenomenon to be managed in secularized 
societies. Our societies are changing to the extent that new groups and new needs appear (Habermas 1999). To make this plurality possible, mutual recognition between people from diverse religion identities based on validity claims (Habermas 1987) is fundamental. In this sense, the concept of multicultural laicism aims at ensuring the religious neutrality of an institution while recognising the right of all people to live in their religious identity (de Botton and Pulido-Rodríguez 2013). Educational environments based on egalitarian dialogue and multicultural laicity already have a remarkable impact on interreligious knowledge, respect for religious diversity, conflict prevention and the acceleration of learning as noted by several authors (Girbés-Peco et al. 2019; Khalfaoui et al. 2021; Coelho and de Lima Constantino 2020).

However, in contrast with the vast collection of research carried out on interreligious dialogue, there is less scientific analysis on the presence of religious plurality in solidarity actions or social movements, and the gap widens when we refer to the analysis of the specific impact that religious plurality and interreligious dialogue has on social mobilisation and the transformation of social inequalities. It is precisely on this point that this paper aims to make a difference.

The starting point in the paper is whether religious plurality (or diversity) is one of the factors that contributes to engaging in social movements. Despite being a debate of great relevance, we are not referring to religious pluralism. As Mittleman (2015) points out, religious pluralism refers to a conception of the common good. In this sense, as Rhodin and Mao (2017) point out when analyzing Habermas, religious pluralism raises the debate and the political implications about how we can live together without renouncing our religious identities. Although we share the great relevance of this debate for the political implications it has in relation to coexistence, in this paper we want to address a previous step, such as whether religious diversity could promote solidarity. Of course, on many occasions, this element leads to the interreligious dialogue and religious pluralism debate (Nizigama 2020), but it is not the main issue of this paper.

Previous research has identified plurality (of gender, age, cultural background, political affiliation and any other feature) as one of the components of social organisations or initiatives that favour their success in generating solidarity with social impact (de Botton and Pulido-Rodríguez 2013). Social, ideological and livelihood plurality have been considered to provide alternative perspectives and creativity that may benefit the strategic capacity of organisations (Ganz 2000). Within plurality, this paper is focused on religious plurality, understood as a descriptive account of theological, ritual and communal differences (Walton and Mahadev 2019). Thus, the research question that guided this study was whether religious plurality can be a facilitating element in motivating involvement in a solidarity initiative.

\section{Materials and Methods}

The data used in this article come from the project Solidus. Solidarity in European societies: empowerment, social justice and citizenship (SOLIDUS 2015-2018), funded under the Horizon2020 Programme of the European Commission. Among other activities, SOLIDUS researchers developed 64 case studies of solidarity initiatives distributed among $12 \mathrm{Eu}-$ ropean countries and different social areas (employment, education, health, housing and civic engagement). These cases were selected from a first inventory of relevant practices and acts of solidarity for each involved country. A main criterion for the selection of the cases was that there was evidence of achieving social impact, meaning that they had led to concrete improvement in their social area. The development of the case studies involved conducting a total of 340 interviews and 12 discussion groups, as well as reviewing more than a hundred documents from the different cases. The case studies were conducted using the communicative methodology (Gómez 2019), which is based on egalitarian dialogue among all of the social agents, researchers and the subjects, involved in the realities analysed. Researchers are committed to sharing existing scientific knowledge, and people involved in the communities being studied contribute to knowledge from their lifeworlds. 
In this interaction, new knowledge appears and offers critical understanding to both parts. Data analysis was conducted according to a set of 6 categories (Democracy, Plurality, Transparency, Social and Political impact, Recognition and Scalability), and a distinction was made between exclusionary and transformative dimensions in each category to identify both barriers and drivers that lead to success in the initiative analysed.

In order to explore the relationship between religious plurality and the motivations for solidarity, we have focused in this paper on a selection within the Spanish context. We selected the cases because they have a relevant presence of religious plurality among their members or/and are addressed to religious minorities. Although religious diversity has a long history in Spain, many religious communities were clandestine during the years of dictatorship until 1975, when the link between the state and the Catholic Church was very strong. The growth of immigration in the last two decades has led to an increase in religious diversity. The two selected cases are (1) interreligious language pairs to learn languages, promoted by the Directorate General for Language Policy of the Generalitat de Catalunya, and implemented with the collaboration of various local entities of the third sector, and (2) Alencop, a social initiative cooperative born as a response to undocumented immigrant settlements in 2013 in the city of Barcelona. Alencop has currently been set up within the Diomcoop cooperative. Both cases are located in Catalonia, a region in which a timid normalisation of religious diversity has begun in recent years (Generalitat de Catalunya 2021).

Data collection took place during 2017 through document research and qualitative fieldwork. For the case of interreligious language pairs, four interviews were conducted: two with stakeholders, and two with end users. For the case of Alencop, the research team conducted five interviews: three with stakeholders, and two with end users.

In addition to the data already gathered for the SOLIDUS project, we updated information through the review of documents and videos published on different websites of the cases analysed (for more information, see the links and additional information in web references) and one more interview with the coordinator of the second case selected. The reason for this update is due to the replicability of this experience in other localities for the first case, and in the second case the experience is transformed and inserted into a broader cooperative of services.

Transcriptions of the interviews were analysed according to the categories used in the case studies under the SOLIDUS project. For this study, we used the excerpts identified as social impact, plurality (especially religious plurality) and democracy. Researchers crosschecked their coding to reach agreement and enhance credibility.

SOLIDUS research was revised and fully approved by the Ethics Committee of the University of Barcelona. The names used in this paper are pseudonyms, except those of participants who offered their permission and are published on the website.

\section{Results}

\subsection{Interreligious Language Pairs}

This initiative has its origins in a previous initiative that started in 2003 on language learning through volunteering, where over the years more than 100,000 language pairs have been formed to learn Catalan. Native people or with high knowledge of Catalan participate as volunteers to talk to newcomers.

From 2014, given the success of this initial language learning programme, the Catalan government decided to introduce religious diversity as another variable in the formation of small language groups, usually pairs. This was done by appealing to different religious entities and especially those dedicated to interreligious dialogue, as well as citizenship in general. The first city to start in Catalonia as a pilot test was Girona (a city in Northern Catalonia). Later this initiative was replicated in other towns (Lloret, Salt, Olot, Badalona and L'Hospitalet). It is a good practice recognised by the European Commission in 2015 (European Cultural Interactions 2007) and has subsequently been implemented in other areas such as Andorra, France (Perpignan), Belgium (Flanders) and Italy (Bolzano). ${ }^{1}$ 
The administration that promoted the initiative explicitly incorporated the religious variable to respond to a current need for social cohesion in a society that is becoming more pluralistic, understanding that mutual knowledge must prevent intercultural conflict. According to the statistics provided, in 2015 a total of 10,022 linguistic pairs were created, which involved a total of 10,173 people: 5987 "apprentices" and 4186 "volunteers". Of these 10,173 people involved, 5702 were totally new to the programme and motivated by religious orientations (such as Catholic, Evangelic, Orthodox, Buddist, Muslim and Sikh, among others) (Generalitat de Catalunya 2015). In this sense, one of the responsibilities of the programme recognises that, beyond the purpose of learning the common languagewhich can be a facilitating element for communication-it is very important to encourage interaction in diversity and dialogue about religion:

The interreligious language pairs programme also breaks the taboo that discussing about religion does not mean that you have to have a belief convictions but simply interested in the cultural aspect of religion (... ) This was a very nice lever, very good because many people get involved. ( ... )

In the same vein, a member of the board for interreligious dialogue in the city of Badalona pointed precisely to the importance of encouraging diverse interactions to promote coexistence. This is done through a purpose such as learning/teaching a common language.

The people who give the homilies are the rectors, the imams, the pastors ... these are the people we have gone to make the proposal to. They are the ones who will explain this project to their parishioners. Sometimes religions have the tendency to close down, it is a challenge to open doors, to see this city and to share. It is not about converting anyone, it is about sharing a space that is Badalona with the different beliefs ( . . ) it is good for the city, for the citizens to know and contrast. (Jaume Ventura, interreligious dialogue board) ${ }^{2}$

The interviews of people from different towns and cities show that all of the interviewees especially value the integrative character of the interreligious language pairs, because it offers the opportunity to get to know different cultures and religions in a way that would not otherwise be possible. Some of the examples concern the town of Salt, in northeastern Catalonia, with almost $40 \%$ of the population coming from different countries. The expressions of solidarity may also build on people's perceptions of what is in one's interest to do, or perceptions of one's interdependence with others, in efforts to change or improve a given situation. In the case of the interreligious language pairs, there are some examples of how people who at one time had just arrived at Salt are now helping members of their communities or other communities to be part of the municipality of Salt. In this regard, they act as volunteers and help to teach the language and culture of Catalonia to their peers. In Salt, a member of the coordinator of the language pairs experience explains:

Within the interreligious language pairs there was a person with migrant origin who knew perfectly Catalan because he came here many years ago and he is now volunteer, and therefore that person, who is Moroccan ( ... ) he is now teaching Catalan to other members of his community ... and that also overcomes barriers because not only those who are Catalan are the ones who teach Catalan, but Catalan can be taught by migrants as well.

An interesting case is the language pair formed by the imam and the Catholic priest of the same village. They feel that, besides increasing their linguistic knowledge, they have learned about the culture and religious tradition of the other, and therefore now understand the reason for some of their actions, thus promoting greater empathy with their own fellow citizens. The priest interviewed explains what he gained in this exchange.

He is the imam and I'm a priest ( . . ) moral authorities rather than governmental authorities ... but we are referents in our communities, and has certain influence 
(... ) we break taboos, prejudices when he explains [the experience of interreligious pairs] to his community and I explain to mine, and that clarifies stereotypes and makes a network (...) our communities have an interest in learning about other ways of thinking, other realities, dig a little deeper.

The initiative offers an opportunity that would otherwise be difficult to relate to people from other groups, which, as some interviewees emphasise, helps to overcome stereotypes towards the other communities.

On the first day I thought that the Catalans were very closed-minded. Now I see that they are not. (Dramane- Muslim from Mali)

I have seen the enormous solidarity of the group and I have been very impressed.

(Enrique, language partner of the Dramane) ${ }^{3}$

Consequently, the participants involved in this action recognised that the action has helped them to understand and relate to people from other cultures present in their environment. These interactions have allowed the creation of bonds of friendship, complicity or solidarity. It is precisely from this emotional dimension that the participants indicate that they have learned about other cultures and have transformed some of their initial prejudices. The variable of religious pluralism for many of the people involved in this solidarity action has motivated participation — the desire to learn-teach the language and get to know other traditions and cultures. For example, one of the participants was a Catalan man in his forties who became involved in the experience by learning about other cultures and religious traditions, and expressed his satisfaction and interest in the fact that he was able to get to know people from other countries and religions:

Thus began a very stable friendship. You only value what is known. There is no prejudice because we know each other and then of course, if there are prejudices with newcomers is because we do not know those people, and we simply see externally that they are different from us and of course, this causes us a suspicion, which is destroyed when you know the other person.

As this quote illustrates, the language pairs generate changes in the biases of the participants belonging to the dominant religious group and thus challenge the Christian normativity of society.

According to the interviews conducted, the majority of the interreligious language pairs have met for more hours than the programme indicates for language learning. One of the volunteers thought that the main reason for this was that the experience actually resulted in friendship throughout the project.

We do more, because we are still ... but no longer in the program because the program was finished this time and got the diploma and all that, it is an incentive, but let's say have begun fact that makes continued friendship not only between us, between $X$ [his pair] and myself but also other pairs. We know other pairs who, instead of meeting every two weeks as we were, as they are every month or month and a half of a house to another house and so began a very stable relationship because here there is a very important value only what is known.

The number of participants in the different towns is relatively small, approximately twenty per town; therefore, we are talking about approximately 150 people. However, these participants act as replicators in their personal environments, allowing them to deactivate or prevent the transmission of particular messages or stereotyped images, thus amplifying the initiative's impact and inviting other people to participate. In addition to the case of the imam and the priest that we have already pointed out and which have a clear community impact, a young man from Mali participating in the initiative after 10 years living in Catalonia emphasised that he does not keep this opportunity to himself but shares it with those around him.

I tell my friends later. (Dramane. See note 3) 
As with Dramane, other participants have acknowledged the importance of the experience in their lives and therefore it is easy for the subject to come up in their conversations with other people.

Currently, this experience has been oriented towards other initiatives also organised by the administration, such as the mentoring of immigrants and refugees with third sector entities' collaboration, where native volunteers want to help refugee and migrant people in order to create a sense of community belonging (Generalitat de Catalunya 2019).

\subsection{Alencop Cooperative}

Alencop is a social economy initiative that was promoted in 2015 by a group of undocumented immigrants with the economic support of the Barcelona City Council, with the aim of responding to two problems. One is the collection and treatment of waste in the city, and the second is to contribute to improving the living conditions of this group (Chaves-Ávila et al. 2020). In this sense, since its inception, it has aimed to regularise existing economic activities, such as scrap metal collection. Many people without papers were engaged in it as one of the few means of subsistence within the underground economy. This experience made it possible to regularise the situation of sub-Saharan people, mainly Muslims and animists from various countries in black Africa, who lived in an occupied ship. People from other religious groups of Christian or polytheistic traditions have also been involved in this experience as volunteers.

The involvement of migrants was fundamental to establishing a cooperative, understood as an answer to the demands of the collective of immigrants and of the community (neighbours), but which could have a positive effect on the community as well:

Next, they carried out a selection of people who wanted to participate in this project at two levels: first of all under individual care, then with debating groups with the entities which is in fact what it is about or how to approach this issue with participants that are on site, but utilising not just the group of immigrants but the whole community as a practical tool: the way the cooperative can become a tool for the community. We do not speak about a group only, but the community as a whole. (Ousmane)

In the first year of its establishment, 15 people were ${ }^{4}$ able to obtain legal residence and work permits with a regular income when they became members of the cooperative. This experience has offered them, in addition to legal security, training and work experience in the business world. As a result, some of these cooperative members left the cooperative in solidarity and undertook their own projects or other work, thus encouraging the entry of other members and facilitating rotation.

As we mention above, this social initiative has relied on volunteers from different groups and religious traditions. These volunteers have contributed to the group's dynamism, the necessary labour training (in office automation, language, occupational hazards and techniques in the treatment of scrap metal, among others), legal support and interrelation with the host society, which has a Christian tradition. One of the Muslim and Catalan volunteers' testimony indicated that his motivation to participate comes from his desire to build a diverse and cohesive society, especially considering that Muslim people are one of the most discriminated against groups.

I don't know them but I want to help them. They were not family, nor friends, I didn't know who they were but their situation is hard and I wanted them to meet a kind face, with a little help that could help them to be autonomous here. (Falu, Alencop volunteer)

Alencop is mainly formed by immigrant people from sub-Saharan countries and Catalonia, all of them from different religious traditions. In addition to the demand for regularisation of the legal situation, the cooperative has another purpose regarding normalising the cultural and religious diversity existing in our society. In this regard, there are people from different countries, ethnic groups, religions, ages, etc. 
However, there are two aspects related to plurality to take into account to understand Alencop. First, the diversity of profiles and expertise is seen as a key element to guarantee the diversification of possibilities within its successful model of business. In fact, when the selection process started on 2014, one of the requisites was the diversification of profiles in order to provide different potentialities and multiple points of view to the cooperative. However, in turn, the challenge was that such a diversity of profiles would need to be integrated and work as one to achieve success. One of the participants in the cooperative indicates that the existing diversity, including religious plurality, is an element of motivation to become involved in the cooperative:

There are many types of members. The idea is to see everybody's possibilities, from a range of people who attended University to those illiterates since reality is definitely diverse (... ) people with different religious beliefs, different cultures, different languages. (Ousmane)

A volunteer acknowledges that she learned about the social economy initiative through an interreligious dialogue association in which she participates. This person points out that what moved her to become involved in the experience by offering training in web and office design is that it offers her the opportunity to get to know cultures present in her society but unknown to her. She thinks that it is through daily contact that she can make friends and overcome existing clichés.

The objective of becoming cooperative members allows the legal situation to be regularised and thus offers this opportunity to others. However, this initial purpose has not been as quickly realised as expected. The regularisation of the population has contributed to an improvement in their housing and the training received has increased their employability in other economic sectors and thus facilitated rotation.

At present, the agreement with the municipality has not been renewed for 2020 due to the project's lack of economic autonomy. The initial objective was to reduce the public contribution thanks to the scrap market, but this has not been possible, a situation where, besides, the reinsertion of the 17 cooperative members has been made complicated by the pandemic ${ }^{5}$.

Several of the members of this cooperative participated and later joined a cooperative created in 2017, Diomcoop, to address a similar vulnerability situation, this time aimed primarily at the group that sells "Top-Manta" on the street. This cooperative social economy initiative extends the objectives of the former to offer a broader range of services. These refer first to logistics and cleaning services. Second, they introduced various Senegalese dishes in gastronomy and catering at events, and more recently on a social network of food supply. Third, a line of sewing and responsible fashion called Diambaar, which has worked with the DonaKolors initiative on some garments, has been aimed at women in vulnerable situations as survivors of trafficking for sexual exploitation. Fourth and finally, there is a more transversal objective of the initiative, such as raising awareness and cultural dissemination. The people who participate in this initiative, both the initial one through Alencop and the current Diomcoop, are members of different nationalities, cultural and religious groups motivated by the desire to overcome inequalities and discrimination that contribute to coexistence in a diverse society. They started with approximately fifteen people who could regularise their legal status and now number approximately thirty people.

What we want is to add up identities. We are from here and from Africa and we can contribute to many things here. And this is what teaches the cooperative in everything it offers. We are different and equal. (volunteer to the cooperative)

One thing that is clear is the need for support and to give to the community what they once received from the community:

Anyone having a professional job should be able to enjoy social work and say: what society has furnished me with, how could I return it to the society? By 
helping in an adult people school, meeting people, making linguistic pairs, volunteer work, in short, anything to return to society what society gave to us. Why? Because, really, if vulnerable groups are not protected, all of us will turn into vulnerable people. We must protect and accompany our neighbours otherwise (... ) all of us will be on track to become vulnerable subjects. (Ousmane)

\section{Discussion}

Our findings from the case study of the interreligious language pairs and the Alencop cooperative suggest that plurality, including religious plurality, is one of the factors that motivates people to continue and reinforce their involvement in solidarity-based initiatives.

In the case of interreligious language pairs, the different interviewees valued religious plurality very positively as they pointed out that it strengthened their commitment to the initiative and cohesion. They admitted that it has helped them overcome preconceived ideas and have a more precise knowledge of the multicultural and multireligious context surrounding them. Participants have acknowledged breaking down prejudices towards the dominant group ("Catalans as closed-minded", for instance) and, importantly, the experience clearly contributed to overcoming stereotypes and discrimination towards ethnic and religious minorities. Participants in Alencop also valued the fact that one of the social initiative's objectives was to normalise the presence of cultural and religious diversity in our society. This has been done by offering other images and references of African culture, far from that presented by the media and present in the collective imagination. The cooperative members of Alencop and Diomcoop also introduce the interest of the exchange between Catalan and African culture, as well as normalise religious diversity, to create a positive image and normalise the diversity present in our society.

In both cases, beyond the fact that there are people of different religions, there are conditions of equal dialogue between them, based on claims of validity (Habermas 1987). Mutual recognition ensures that interaction and exchange can take place between all the participants and enable both mutual learning and internal democracy. Moreover, this dialogue has promoted bonds of friendship and complicity contributing to the management of religious diversity in the public sphere. Beyond mutual understanding and coexistence, these solidarity initiatives have achieved other social impacts such as language learning (language pairs) and the legal regularisation of more than twenty people (Alencop), with the consequent improvement in living conditions and opportunities.

The understanding of religious plurality and interreligious dialogue as a driver of solidarity has implications for social policies and for the management of civil society organisations (Habermas and Ratzinger 2006). Initiatives aimed at promoting social changes should consider and promote the religious plurality among the group as an element that may encourage the participation and commitment of participants. However, further research should expand these results with the analysis of more initiatives located in diverse geographic, social and political contexts, as well as concerning different social actions.

Another future line of work would be to explore in more depth the impact that plural organizations have on the normalisation of religious diversity in our societies and the extent to which they promote religious pluralism.

Author Contributions: Conceptualization L.d.B., M.P.; Methodology, L.d.B., M.P.; Validation E.A., P.M.; Formal Analysis, E.A., L.d.B.; Original Draft Preparation, L.d.B.; Writing-Review \& Editing, L.d.B., E.A., M.P., P.M. All authors have read and agreed to the published version of the manuscript.

Funding: This research was funded by the European Commission, H2020 project SOLIDUS. Solidarity in European societies, Grant Agreement number 649489.

Institutional Review Board Statement: The study was conducted according to the guidelines of the Declaration of Helsinki, and approved by the Ethics Committee of the University of Barcelona (approved on 2 June 2016).

Informed Consent Statement: Informed consent was obtained from all subjects involved in the study. 
Data Availability Statement: The data presented in this study are available on request from the corresponding author. The data are not publicly available due to agreements signed with people in order to protect their personal data. Some data used are available in a publicly accessible repository that does not issue DOIs. This data can be found here: http:/ / www.bbp.cat/practicas_detalle_imp. php?id_ficha=1203 (accessed on 18 July 2021) or https: / www.youtube.com/watch?v=z1FZyFJGr3

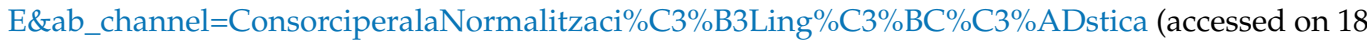
July 2021) or https: / / www.fundaciosergi.org/una-jornada-a-girona-dona-a-coneixer-el-voluntariatper-la-llengua-amb-parelles-interreligioses / (accessed on 18 July 2021).

Conflicts of Interest: The authors declare no conflict of interest.

\section{Notes}

1 http:/ / www.bbp.cat/practicas_detalle_imp.php?id_ficha=1203 (accessed on 18 July 2021).

2 https://www.youtube.com/watch?v=AgPxSPsTGLs\&ab_channel=BadalonaComunicaci\%C3\%B3 (accessed on 18 July 2021).

3 https://www.youtube.com/watch?v=z1FZyFJGr3E\&ab_channel=ConsorciperalaNormalitzaci\%C3\%B3Ling $\%$ C3\%BC\%C3\%ADstica (accessed on 18 July 2021).

4 http://ajuntament.barcelona.cat/dretssocials/noticia/barcelona-crea-una-cooperativa-de-recollida-de-ferralla (accessed on 18 July 2021).

5 https://www.ara.cat/societat/Ajuntament-deixa-caure-cooperativa-ferrallera-Alencop-conveni_0_2475952421.html (accessed on 18 July 2021).

\section{References}

Ahn, Ilsup. 2019. Reconstructing an ethics of credit in an age of neoliberalism. Religions 10: 484. [CrossRef]

Astor, Avi, Mar Griera, and Mónica Cornejo. 2019. Religious governance in the Spanish city: Hands-on versus hands-off approaches to accommodating religious diversity in Barcelona and Madrid. Religion, State E Society 47: 390-404.

Baker, John, Kathleen Lynch, Sara Cantillon, and Judy Walsh. 2009. Equality: From Theory to Action. Basingstoke: Palgrave Macmillan.

Balboa, Orfeo, and Benno Herzog. 2016. Antisionismo: Judeofobia sin Judíos y Antisemitismo sin Antisemitas. Scientific Journal on Intercultural Studies 2: 118-139. [CrossRef]

Bauhr, Monika, and Nicholas Charron. 2020. In God we Trust? Identity, Institutions and International Solidarity in Europe. JCMS: Journal of Common Market Studies 58: 1124-43. [CrossRef]

Berger, Peter. 2014. The Many Altars of Modernity: Toward a Paradigm for Religion in a Pluralist Age. Boston and Berlin: De Gruyter.

Campdepadrós-Cullell, Roger, Miguel Angel Pulido-Rodríguez, Jesús Marauri, and Sandra Racionero-Plaza. 2021. Interreligious Dialogue Groups Enabling Human Agency. Religions 12: 189. [CrossRef]

Chaves-Ávila, Rafael, Jordi Via Llop, and Jordi Garcia i Jané. 2020. El Pla d’Impuls de l’Economia social i solidaria de la Ciutat de Barcelona. In La nueva generación de políticas públicas de fomento de la economía social en España (Tirant lo, pp. 343-78). Available online: https:/ / dialnet.unirioja.es/servlet/libro?codigo=784110 (accessed on 18 July 2021).

Coelho, Marciele Nazaré, and Francisca de Lima Constantino. 2020. Contributions of Brazilian educational policies: Possibilities for dialogue and valuing ethnic and racial diversity in the school context. International Journal of Roma Studies 2: 41-63. [CrossRef]

de Botton, Lena, and Miguel Ángel Pulido-Rodríguez. 2013. Une Nouvelle Laïcité Multiculturelle. RIMCIS. International and Multidisciplinary Journal of Social Sciences 2: 236-56. [CrossRef]

Durkheim, Emile. 1912. Les formes élémentaires de la vie religieuse. Le système totémique en Australie (Les Presse). Available online: http:/ / classiques.uqac.ca/classiques/Durkheim_emile/formes_vie_religieuse/formes_vie_religieuse.html (accessed on 18 July 2021).

Edwards, Sachi. 2018. Critical reflections on the interfaith movement: A social justice perspective. Journal of Diversity in Higher Education 11: 164-81. [CrossRef]

Ekman, Mattias. 2019. Anti-immigration and racist discourse in social media. European Journal of Communication 34: 606-18. [CrossRef]

European Commission. 2019. Special Eurobarometer 484 Report Perceptions of Antisemitism. Available online: https:/ / data.europa. eu/data / datasets/s2220_90_4_484_eng?locale=en (accessed on 18 July 2021).

European Cultural Interactions. 2007. Ten Successful Ways to Motivate Language Learners. Available online: https://www.vxl.cat/ sites/default/files/materials/ten_successful_ways_to_motivate_language_learners.pdf (accessed on 18 July 2021).

Fadel, Mohammad. 2020. Muslim Theologies of Solidarity and Disavowal and the Challenge of Religious Pluralism. Political Theology 21: 303-317. [CrossRef]

Ferraro, Fabrizioand Daniel Beunza. 2018. Creating Common Ground: A Communicative Action Model of Dialogue in Shareholder Engagement. Organization Science 29: 1187-207. [CrossRef]

Flecha, Ramon. 1999. Modern and Postmodern Racism in Europe: Dialogic Approach and Anti-Racist Pedagogies. Harvard Educational Review 69: 150-172. [CrossRef]

Ganz, Marshall. 2000. Resources and Resourcefulness: Strategic Capacity in the Unionization of California Agriculture, 1959-1966. American Journal of Sociology 105: 1003-62. [CrossRef] 
Generalitat de Catalunya. 2015. Dades del Programa VXL de l'any 2015 [Data of the VxL Programme, Year 2015]. Barcelona: Generalitat de Catalunya.

Generalitat de Catalunya. 2019. Programa de Mentoria de persones sol-licitants de protecció internacional o refugiades. Available online: https://treballiaferssocials.gencat.cat/web/.content/03ambits_tematics/05immigracio_refugi/Persones_refugiades / Programa_catala_refugi/Presentacio_Programa_Mentoria.pdf (accessed on 18 July 2021).

Generalitat de Catalunya. 2021. Mapa Religiós de Catalunya [Religious Map of Catalonia]. Available online: http://justicia.gencat.cat/ $\mathrm{ca} /$ ambits/afers-religiosos/estudis/Mapa/ (accessed on 18 July 2021).

George, Stacy Keogh. 2020. Luca Mavelli and Erin K Wilson (eds), The Refugee Crisis and Religion: Secularism, Security and Hospitality in Question. International Sociology 35: 225-227. [CrossRef]

Girbés-Peco, Sandra, Reginal Gairal-Casadó, and Luis Torrego-Egido. 2019. The participation of Roma and Moroccan women in family education: Educational and psychosocial benefits / Participación de mujeres gitanas y marroquíes en la formación de familiares: Beneficios educativos y psicosociales. Cultura y Educación 31: 754-79. [CrossRef]

Gómez, Aitor. 2019. Science with and for Society through Qualitative Inquiry. Qualitative Inquiry 27: 10-16. [CrossRef]

Gustafson, Hans. 2020. Defining the Academic Field of Interreligious Studies. Interreligious Studies and Intercultural Theology 4: 131-54.

Habermas, Jürgen. 1987. Teoría de la Accion Comunicativa. Vol.I: Racionalidad de la Accion y Racionalizacion Social. Vol. II: Critica de la Razon Funcionalista. Madrid: Taurus.

Habermas, Jürgen. 1990. Justice and Solidarity: On the Discussion Concerning Stage 6. In The Moral Domain: Essays in the Ongoing Discussion between Philosophy and the Social Sciences. Edited by Thomas E. Wren. Boston: Massachusetts Institute of Technology, pp. 224-50.

Habermas, Jürgen. 1999. La inclusión del Otro. Estudios de Teoría Política. Paidós: Barcelona.

Habermas, Júrgen, and Joseph Ratzinger. 2006. Dialéctica de la Secularización. Sobre la razón y la Religión. Madrid: Encuentro.

Haerpfer, Christian, Ronald Inglehart, Alejandro Moreno, Christian Welzel, Kseniya Kizilova, Jaime Diez-Medrano, Marta Lagos, Pippa Norris, Edward Ponarin, and Bi Puranen. 2020. World Values Survey: Round Seven-Country-Pooled Datafile. Madrid: World Values Survey Association. [CrossRef]

Hein, Jeremy, and Tarique Niazi. 2016. The primordial refugees: Religious traditions, global forced migration, and state-society relations. International Sociology 31: 726-41. [CrossRef]

Khalfaoui, Andrea, Rocío García-Carrión, and L. Lourdes Villardón-Gallego. 2021. A Systematic Review of the Literature on Aspects Affecting Positive Classroom Climate in Multicultural Early Childhood Education. Early Childhood Education Journal 49: 71-81. [CrossRef]

Kyriakidou, Maria. 2021. Hierarchies of deservingness and the limits of hospitality in the 'refugee crisis'. Media, Culture $\mathcal{E}$ Society 43 : 133-149. [CrossRef]

Miles-Tribble, Valerie. 2020. Change agent teaching for interreligious collaboration in Black Lives Matter times. Teaching Theology $\mathcal{E}$ Religion 23: 140-50. [CrossRef]

Mim, Nusrat Jahan. 2020. Religion at the Margins: Resistance to Secular Humanitarianism at the Rohingya Refugee Camps in Bangladesh. Religions 11: 423. [CrossRef]

Mittleman, Alan. 2015. Religious Pluralism and Values in the Public Sphere, by Lenn E. Goodman: An Appreciation and Critique. Political Theology 16: 49-501. [CrossRef]

Nizigama, Isaac. 2020. Understanding the "new religiou pluralism": The approach of Peter L. Berger. Studies in Religions-Sciences Religieuses 49: 109-36. [CrossRef]

Nussbaum, Martha. 2001. Upheavals of thought. Cambridge: Cambridge University Press.

Oman, Natalie. 2010. Hannah Arendt's "Right to Have Rights": A Philosophical Context for Human Security. Journal of Human Rights 9: 279-302. [CrossRef]

Perednik, Gustavo. 2018. Juedeofobia. las Causas del Antisemitismo, su Historia y su Vigencia Actual. Buenos Aires: Sudamericana.

Perrineau, Pascal. 2014. La France au Front: Essai sur l'avenir du Front National. Paris: Fayard.

Pew Research Center. 2018. Being Christian in Western Europe. Available online: https://www.pewforum.org/2018/05/29/beingchristian-in-western-europe/ (accessed on 18 July 2021).

Rhodin, Lars, and Xin Mao. 2017. Religious pluralism: A Habermasian questioning and a Levinasian addressing. Journal for the Study of Religions and Ideologies 16: 49-62.

Robra, Martin. 2000. Affirming the Role of Global Movements for Global Ethics. The Ecumenical Review 52: 471-78. [CrossRef]

Rorty, Richard. 1989. Contingency, Irony, and Solidarity. Cambridge: Cambridge University Press.

Sen, Amartya. 2019. Gods, gurus, prophets and the poor: Exploring informal, interfaith exchanges among working class female workers in an Indian City. Religions 10: 531. [CrossRef]

SOLIDUS. 2015-2018. Solidarity in European Societies: Empowerment, Social Justice and Citizenship. Horizon 2020 (2015-2018). Available online: http:/ / solidush2020.eu/ (accessed on 18 July 2021).

Steinbach, Anja, and Merril Silverstein. 2020. The Relationship Between Religion and Intergenerational Solidarity in Eastern and Western Germany. Journal of Family Issues 41: 109-30. [CrossRef]

Than, Krisctina, and Gergely Szakacs. 2018. Hungary's Strongman Viktor Orban Wins Third Term in Power. Reuters. Available online: https:/ / www.reuters.com/article/us-hungary-election-idUSKBN1HE0UC (accessed on 18 July 2021). 
Torrens, Xavier. 2006. Racismo y antisemitismo. In Ideologías y Movimientos Políticos Contemporáneos. Edited by J. Anton Mellon. Madrid: Tecnos, pp. 347-80.

Walton, Jeremy, and Neena Mahadev. 2019. Introduction: Religious Plurality, Interreligious Pluralism, and Spatialities of Religious Difference. Religion and Society 10: 81-91. [CrossRef]

Wieviorka, Michel. 1992. El Espacio del Racismo. Barcelona: Paidós. 